\title{
JUURNAL.RU
}

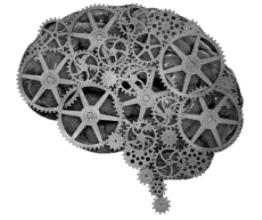

COMPANY GROUP "INTELLEKT"

Косырева М.С. Сибирский институт управления - филиал Российской академии народного хозяйства и государственной службы при ПрезидентеРоссийской Федерации Новосибирск, Россия

doi: 10.18411/lj2016-8-1-07

idsp 000001:lj2016-17-1-07

\section{Истоки интернациональной лексики в русском языке}

Общеизвестно, что современный русский язык как литературный сформировался к началу ХІХв. В совокупном действии фундаментальных тенденций к экономии языковых средств и унификации системы языка, с одной стороны, и тенденции к расширению средств выразительности, с другой стороны, на уровне лексико-семантическом более значимой оказывается последняя. Контакты русского языка с языками Запада и Востока в связи с внутренними закономерностями развития самого русского языка на разных ступенях эволюции порождали и расширяли интернациональное начало в лексике и фразеологии русского языка. В данной работе мы анализируем истоки и динамику развития интернационализмов в русском языке до периода оформления его как литературного.

Принято говорить о первых явлениях интернационализации русской лексики с возникновением в $\mathrm{X}$ веке в период христианизации восточных славян письменного древнерусского языка[1]. К эпохе праславянской общности восходят лишь единичные интернационализмы (например,вино). Древнерусская же письменная речь благодаря сочетанию старославянского языка как общелитературного языка славянства $\mathrm{IX}-\mathrm{X}$ вв.и восточнославянского (древнерусского) начала оказалась сразу же включенной в греко-славянский мир в целом.

Старославянский язык, легший в основу церковно-книжного типа языка, принес в древнерусский язык многочисленные грецизмы (например, аметист, 
аминь, анафема, апокалипсис, апостол, аромат, астролог, деспот, дьявол и мн. др.). Заимствование иноязычной лексики стимулировалось тем, что в древнерусском и старославянском языках не всегда находились свои формы для выражения новых понятий. Подобная лексика приходит с общеевропейскими понятиями: например, появление в древнерусском языке через старославянское и византийское посредство латинских названий месяцев, общих с западноевропейскими языками, означало изменение понятий года, времени года, месяца. Важным путем проникновения и распространения заимствований были многочисленные переводы.

Интернационализмы греческого происхождения проникали в древнерусскую письменную речь и минуя старославянское посредство. Восточнославянскими диалектами непосредственно из среднегреческого языка устным путем заимствовалась бытовая лексика (например, вишня, лиман, мак, цыган) в результате непосредственных связей с Византией и ее черноморскими колониями. Последнего рода слова позже объединят русский язык с рядом языков Балкан и вообще Восточной Европы.

Интернационализмы восточноевропейского или также кавказского и ближневосточного распространения стали проникать в древнерусский язык устным путем через тюркские языки (например, базар, булат, казна, кафтан и т. д.). Вплоть до XIV в. именно они были основным источником интернациональной лексики.

B XIV-XVI вв. на основе частей ранее единой древнерусской народности постепенно формируются три близкородственные народности со своими языками. С этого времени история интернационализации словаря русского языка несколько отличается от аналогичных процессов в украинском и белорусском языках, несмотря на тесные связи всех трех языков. На великорусской почве длительное время продолжают развиваться стилистические традиции древнерусского языка, но уже в XV-XVI вв. здесь нарастает роль норм московской деловой письменности, превращающихся в стиль светского языка, противостоящий церковно-книжному стилю языка. Попрежнему за пределами литературной нормы остается разговорно-бытовая речь.

Интернациональные элементы проникают в церковно-книжную письменную речь и в ходе так называемого «второго южнославянского влияния» 
(с конца XIV — начала XV в. по конец XVI в.) в результате усиления влияния греческого языка. Кроме того, продолжается проникновение тюркских элементов и ориентализмов через тюркское посредство в разговорную речь.

Интернационализация словаря заметно усиливается в ходе формирования русского национального языка в XVII-начале XVIII в. В этот период завершается начавшийся еще со второй половины XVI в. процесс образования единой системы литературного языка с тремя стилями, объединившей славянские и собственно русские элементы. Не порывая традиционных связей с греко-славянским миром, русский язык все более начинает вступать в контакты с языками Западной Европы.

B XVII в. славяно-русский тип книжного языка обогащается заимствованиями не только из греческого языка, но и из латыни. Здесь сказывается развитие в Московской Руси с XVI в. богатой переводной литературы с латинского, польского, немецкого языков, организация латинского образования в Москве, польское и украинское влияние. Вырабатывается латинский звуковой стереотип оформления заимствований, причем повторные заимствования ведут к преобразованию части грецизмов по новому стереотипу (иконном - эконом, артирия- артерия, акадимия - академия, кентр центр, кентавр - центавр, стратиг- стратег и т. п.). Сохранение в русском языке следов как греко-византийского, так и латинского стереотипов привело к непоследовательности звуко-буквенных соответствий ряда интернационализмов в русском и западноевропейских языках. Наряду с грецизмами в латинской оболочке приходят и собственно латинизмы (например, аффект, инструмент, глобус, градус, дистанция и пр.). Проводником влияния европейских языков на русский в XVII в. был польский язык. Вместе с полонизмами и приходят слова аптека, солдат, майор, монарх, музыка, приватный и т.п.

Переломным в истории интернациональной лексики русского языка считается период конца XVII-первой четверти XIX в., когда активно формировался русский литературный язык. В это время устанавливались грамматические нормы языка, в определенной мере стали закладываться основы современной стилистики, происходили коренные перемещения старых лексических элементов в сочетании с множеством новых, в том числе интернациональных. Русский язык вступил в непосредственные и все более 
частые контакты с западноевропейскими, что ускорило сближение его лексики (и не только лексики) с другими языками Европы[2].

Петровская эпоха характеризовалась бурным притоком западноевропейских заимствований, обусловленным причинами как внешнего по отношению к лексике порядка (возникновением множества новых явлений и понятий, стилистическими сдвигами в языке, языковой модой), так и внутренними факторами (отсутствием в языке лексических форм для воплощения этих понятий). Новая лексика и терминология, часто интернационального распространения, приходит через еще более участившиеся сравнительно с XVII веком переводы и распространяющийся индивидуальный полилингвизм[1]представителей просвещенной части русского общества.

На первое место среди исторических источников заимствований выступает немецкий язык, оттесняющий польский, хотя последний еще сохраняет определенное влияние, в частности, при передаче латинизмов. Заимствования осуществляются также из голландского, английского, французского и итальянского языков. Конкретные источники заимствований в различных терминологических сферах оказывались неодинаковыми. Например, для военной терминологии это были немецкий и французский языки, хотя новые термины встречались с уже существовавшими русскими и польскими терминами и некоторыми ориентализмами.

В язык петровской эпохи входит, прежде всего, нужная для него специальная терминология: научно-техническая и производственная, военная и морская, официально-административная и общественно-политическая. Наряду с собственно новыми терминами (например, физика, геометрия, фрегат, навигация, генерал, адмирал) возникает книжная терминологическая и культурная лексика (например, календарь, мода, фантазия, театр, публика, триумф) и модные слова, оттесняющие русские названия знакомых явлений (например, виктория, баталия, кураж, конфуз, пардон и т.п.).

Начиная с 1740-х гг. и почти до конца XVIII в.процесс заимствованияинтернациональных слов происходит главным образом за счет французского языка - авторитетнейшего языка Запада XVII-XVIII вв., знание которого в России надолго становится средством приобщения к культурным ценностям Европы.Во второй половине XVIII в. распространяется 
противодействие употреблению иностранных слов, объясняемое стремлением защитить еще неустойчивую систему русского языка, отсутствием твердых лексических норм, неупорядоченным использованием заимствований, нередко используемых как смысловые дублеты русско-славянских слов и калек. Формы многих заимствований оказываются неопределенными, возникают ряды фонетических и словообразовательных вариантов одних и тех же слов (например, театр-феатр, проба-пробация, визит-визитаи пр.). Прямое заимствование во второй половине XVIII в. сократилось, зато увеличился приток калек, что в ряде случаев вело к созданию в языке международных аналогов.

Таким образом, корпус интернациональной лексики русского языка интенсивно пополнялся за счет заимствований из западных и восточных языков начиная с X в. К концу XVIIІв. установились словообразовательные отношения между определенными разрядами интернациональных слов, стали вычленяться некоторые международные морфемы и основы, появляться словообразовательные типы, что повлияло и на использование, и на дальнейшую судьбу интернационализмов в русском языке.

\section{Литература:}

1. Акуленко В.В. Вопросы интернационализации словарного соста $\neg$ ва языка. Харьков, 1972.

2. Виноградов В.В. Очерки по истории русского литературного языка XVII — ХІХ вв. 3-е изд. М., 1982. 